\title{
Sustainable Assets of Fishermen Household Livelihood Headed by Women: A Case Study of Malangrapat Village, Bintan District, Riau Islands, Indonesia
}

\author{
Khodijah $^{1}$, Elfindri ${ }^{2}$, Rahmat Syahni. ${ }^{3}$ dan Alfian Zein ${ }^{4}$ \\ ${ }^{1}$ Doctoral students of Agricultural Sciences, Andalas University, Padang Indonesia \\ ${ }^{2}$ Lecturers and Professor of Economics, Andalas University, Padang Indonesia \\ ${ }^{3}$ Lecturers and Professor of Agricultural, Andalas University, Padang Indonesia \\ ${ }^{4}$ Lecturers in the Faculty of Marine Sciences and Fisheries, Bung Hatta University, Padang Indonesia \\ Corresponding author: Khodijah, Email: khodijah@umrah.ac.id
}

\begin{abstract}
The Sustainable of livelihood assets is very important for fishermen household headed by women, which the numbers continue to indicate an increase in the last decade. In the province of Riau Islands, more than $80 \%$ of its administration is a coastal village with a most of the population poor, and more than $50 \%$ of the poor are women vulnerable to socio-economic as head of household. Therefore the importance of the sustainable assets of livelihood is not only on financial assets but also the social, physical, human resources and personal assets. In the Malangrapat village, although the results of a survey of 29 fishermen households headed by women indicate a relatively low socio-economic characteristics but the personal assets of fishermen households headed by women has the potential to be optimized in establish the livelihoods sustainable. The data indicates that unsustainable livelihood status is financial assets $(15,93)$, less sustainable status is social assets $(28,19)$, physical assets $(31,71)$ and human resources assets $(32,88)$. Dimensions that support sustainable livelihoods of fishermen households headed by women is a personal asset to value sustainability index of 58, 25 . The result of this observation will highlight how the dimensions of personal assets can be used as the main actors to influence other livelihood assets in the form of sustainable livelihoods and poverty alleviation can be a solution for the particular fishermen households headed by women.
\end{abstract}

Keywords: Personal assets, poverty, fishermen households headed by women, sustainable livelihoods

\section{INTRODUCTION}

In Asia, poverty described mostly are women, most of them lead households, without owning the land, moving, in some cases they are socially excluded and as fishermen in the coastal areas, almost all of Asia they rely on natural resources to establish and develop livelihoods [1] and poverty can begin at home [2]. Therefore, the policy of sustainable development, households headed by women currently a contemporary issue and crucial [3]. Proved in the last decade occurred tendencies increase in the number of households headed by women [4-5], such as in Indonesia from $12.9 \%$ in 2007 to $13.91 \%$ in 2011 [6] and $12.03 \%$ of the population of women socioeconomically vulnerable are in rural [7], even for the age group $45-59$ years, there were more than $50 \%$ of poor women socio-economically vulnerable as head of household [8] and $43 \%$ work in the agricultural sector [9]. It means the higher the number of poor people in rural areas, the higher the number of women's socio-economic vulnerable as head of household. It would be serious socio-economic problems in Indonesia, because until 2013, the BPS data [10] indicate the number of poor is much higher in rural than urban areas with a ratio of $14.32 \%$ : $8.39 \%$ The issue is how the poor household livelihoods can be sustained [11]. Sustainability is defined as how the interaction of social and natural systems, how these reactions affect the sustainability challenges that can meet the needs of current and future generations while substantially reducing poverty and preservation plan as a life-support system [12]. Sustainable livelihoods in detail consists of: 1) they are able to cope with and recover from shocks and stress through coping strategies and adaptation; 2) economically effective; 3) ecological, ensuring that livelihood activities do not degrade the natural resources in a particular ecosystem; 4) social justice, which suggests that promotion of livelihood opportunities for the group did not close the option for other groups, either now or in the future [13]. To be sustainable, a livelihood should be addressed at the level of households and communities, this is important in social equality in getting livelihood opportunities so evenly distributed among households. Even as the anti-poverty approach, sustainable livelihoods philosophy focuses on women (women centered), empowerment, explores what makes the vulnerability of women on a macro level and analyze women asset at the micro level (activist on two levels), committed to the long-term results, by identifying livelihood assets in order for women to get out of poverty [14]. 
Sustainable livelihoods framework, further highlights the assets than income, identify an overview of poverty as limited ability of individuals or households that shows the vulnerability of the system, the trends and shocks of life [15]. Asset is sections that build sustainable livelihoods at the level of individuals, households and communities which is divided into 5 sections [14], namely: 1) Social assets. These assets are shown to the social connections that illustrate how women can achieve their goals, 2) Physical assets. Physical assets include women's basic needs for housing and food, as well as access to services and information to develop livelihood, 3) Human resource assets. Assets are aimed at how women can work associated with the skills, knowledge, education and leadership, 4) Personal assets. Personal assets are assets that connect the women's feelings of personal with cultural identity. These assets include self-confidence, self-esteem, motivation, and the other strength of women who bring to the process of personal transformation, 5) Financial assets. Financial assets are revenue, money and financial security (including access to finance from the government).

\section{RESEARCH METHODS}

This research carried out by purposive in Malangrapat village, one of the largest fishing village in Bintan District, province of Riau Islands Indonesian, has a very strategic location and close to neighboring Singapore and Malaysia with the coordinates $1^{\circ} 6^{\prime} 37^{\prime \prime} \mathrm{N}, 104^{\circ} 34^{\prime} 45^{\prime}$ ' W (See Figure 1).

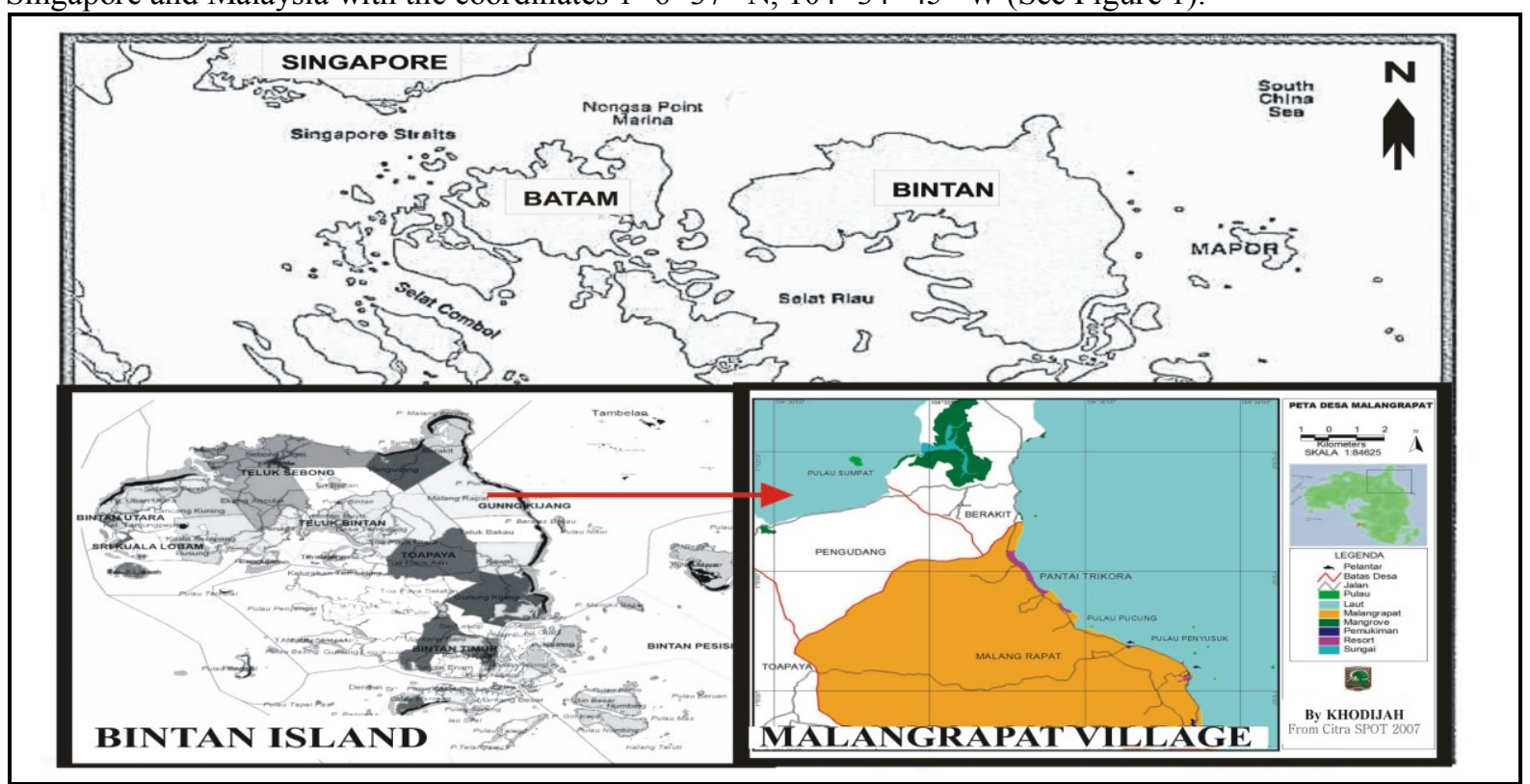

Fig. 1 Map the location of the research

(Source: SPOT image of 2007 and was developed with GTS by Khodijah)

This research is a case study [16] with qualitative and quantitative descriptive approach [17-18]. The unit of analysis of this research is fishermen households headed by women whose numbers obtained by census. While respondents determined by non probability purposive sampling method [17] where one of the respondents who encountered verified, sampled according to objectives and criteria. De Vos et al in [19]. Data were collected through semi-structured interviews using an interview guide with a set of qualitative scale. The analysis step for determining the status of sustainable livelihood assets through the following stages:

a. Index calculation [20]. Index calculation is done by normalizing the data, with the following steps:

\begin{tabular}{|c|c|c|c|}
\hline$(\bar{X} \mathbf{A})$ & $=$ & $\frac{\Sigma \text { score obtained }}{\text { Number of respondents }}$ & ..Step 1) \\
\hline$(\bar{X} \mathbf{B})$ & $=$ & $\frac{\sum(\bar{X} \mathbf{A})}{\text { Number of attribute }}$ & ..Step 2) \\
\hline $\begin{array}{l}\text { Sustainability } \\
\text { Indeks }\end{array}$ & $=$ & $\frac{\Sigma(\bar{X} \mathbf{B})-\Sigma \text { score minimum }}{\text { score maksimum }-\Sigma \text { score minimum }}$ & 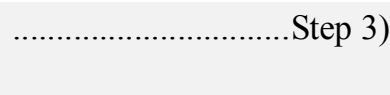 \\
\hline
\end{tabular}

Description:

$(\bar{X} \mathbf{A})=\bar{X}$ score of total attribute 
$(\bar{X} \mathbf{B})=\bar{X}$ score of total dimension

b. Sustainability Status Determination. Sustainability index scale lays between 0-100, then by using Microsoft Excel program, the sustainability index visualized with diagrams radars.

Table 1. Index Category and Sustainability Status

\begin{tabular}{|c|c|c|}
\hline Index Value & Index Category & Sustainability Status \\
\hline $00.00-25.00$ & Bad & Unsustainable \\
\hline $25.01-50.00$ & Less than satisfactory & Less sustainable \\
\hline $50.01-75.00$ & Satisfactory & Sustainable enough \\
\hline $75.01-100.00$ & Good & Highly sustainable \\
\hline
\end{tabular}

c. Determination of dimensions of potential Livelihoods Assets. The analysis stage using the "centrality and power analysis" by analysis tools such as UNICET software, version 6.85 [21], this software is a comprehensive program that is often used to analyze social network data and other data and most appropriately used in the analysis of sustainability. The data used in this analysis is the score value from a qualitative scale from poorly defined (1) to good (4). Output analysis results visualization sosiogram or NetDraw shaped [22]

\section{RESULTS AND DISCUSSION}

\subsection{Characteristics of Fishermen Household Headed by Women}

Previously, established household criteria which is referred to as fishermen households headed by women, namely 1) the de jure permanent, as the household heads [23] because household life without partner, in the sense not to marry or have divorced, divorced and not remarried or widowed and not remarried [24, 9; 25-26] or by the term of permanent female headed household; 2) persistent search for family living (persistent female breadwinner) in the context of economic family [27]. Furthermore, from 29 households were established, the results of the survey showed that $72 \%$ of whom are widows whose husbands died (See Figure 2).

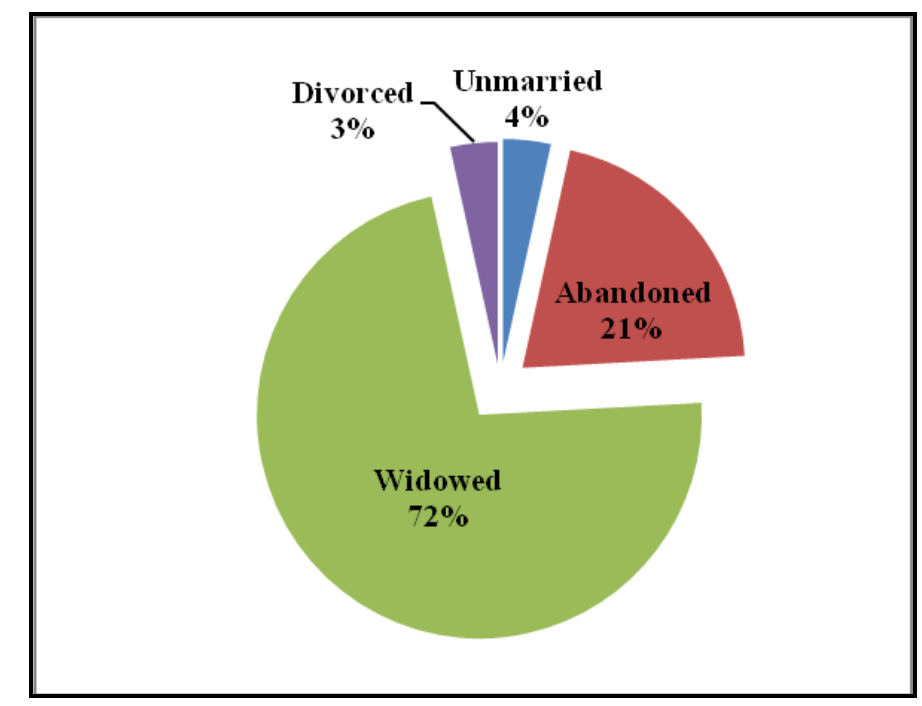

Fig. 2 Marital status of female heads of household (Primary Data)

All heads of households are in the productive age group is $58.62 \%$ (51-65 years) and $41.38 \%$ (20-50 years) with $62 \%$ of them just graduated from elementary school (See Figure 3 ). 


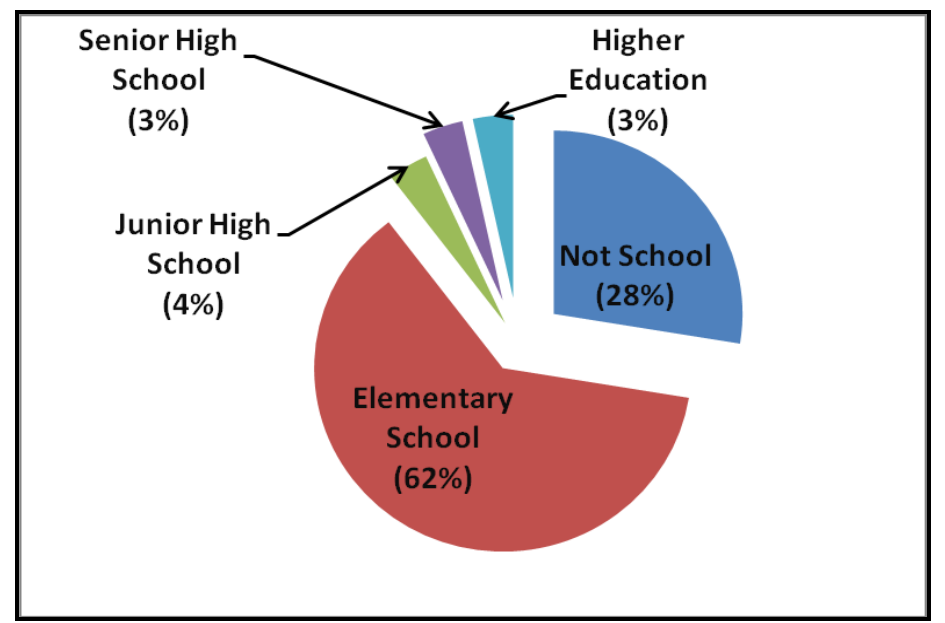

Fig. 3 Education levels of female head households (Primary Data)

And education level for household members can be seen in Figure 4 below.

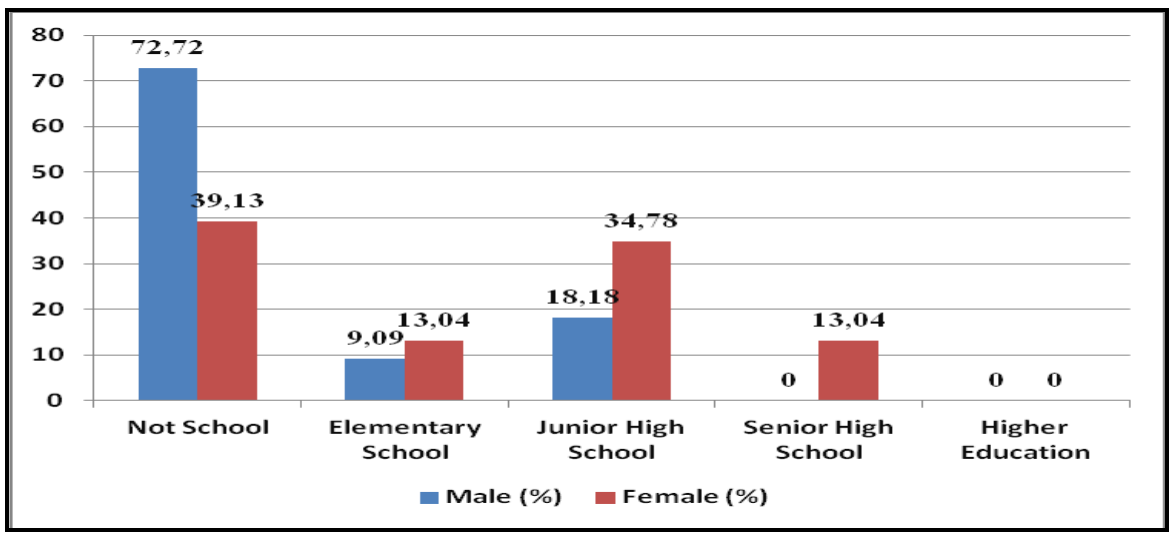

Fig. 4 Education level for household members

In addition to the aggregate poverty index data shows the status of medium but approach poor is 56,32 with the highest needs level in the basic physiological needs $(2,45)$. On the other hand, the environmental context index on average relatively well of 60.36 and this indicates that the well-being of the environment can not be used optimally by fishermen households headed by women. So there are many works to do, in order to fulfill both fishermen and non fishermen needs.

\subsection{Sustainable Assets of Fishermen Household Livelihood Headed by Women}

All assets dimension of fishermen household livelihood headed by women of Malangrapat village, the data showed relatively low and unsustainable. Each of those livelihood assets dimension (see Figure 5) which known to have personal assets as the only asset that has status of quite sustainable, while the dimensions of human resources, physical and social status are less sustainable, and financial dimensions indicate unsustainable status. The sustainable of personal assets dimension can be seen from several attributes, namely: a) self confidence, b) motivation, c) self reliance, d) balancing work and personal life, e) self esteem and assertiveness, and f) freedom. Attributes that best supports the sustainability of the livelihoods of personal assets is self reliance. 


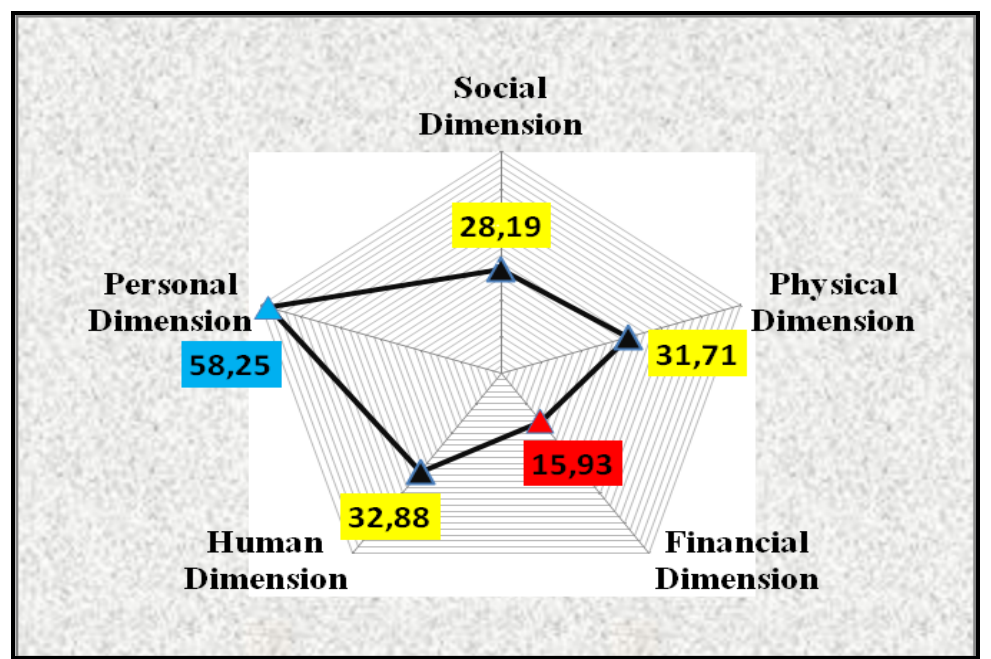

\section{Fig. 5 Sustainable Assets Status of Fishermen Household Livelihood Headed by Women}

Sustainability dimensions of personal assets seen from several attributes, namely: a) self-esteem, b) motivation, c) self reliance, d) balancing work and personal life, e) self-esteem and assertiveness, and f) freedom. Attributes that most support the sustainability of personal assets livelihood are self reliance. Furthermore, sustainable status all the assets dimensions of households livelihood headed by women in Malangrapat village can be seen in Figure 6 below.

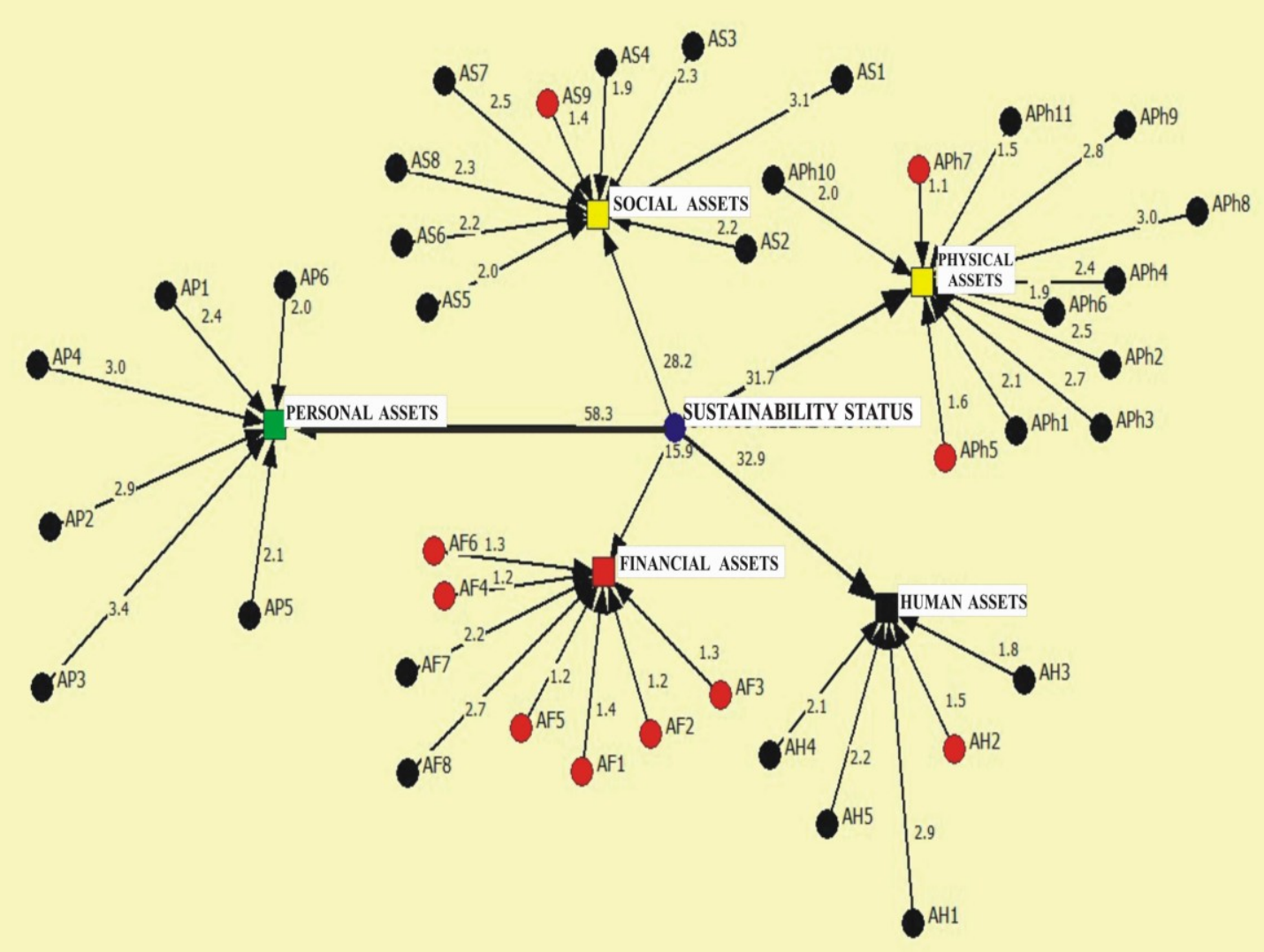

Fig. 6 Visualization of dimensions and attributes sociogram (NetDraw) that affect sustainability

While the dimensions power of personal assets as the main actor of sustainable livelihoods establishment can be seen in the following Ucinet diagrams (Figure 7).. 


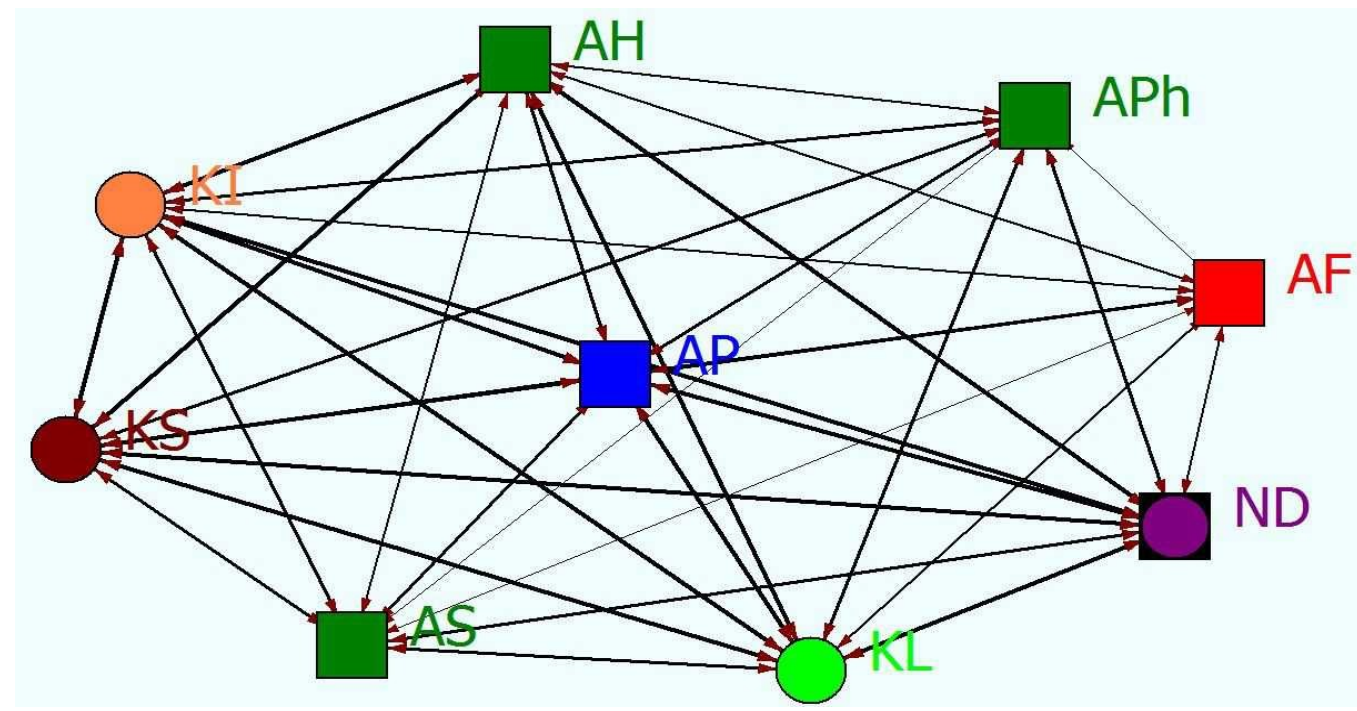

Fig. 7 Visualization of centrality and power analysis inter-dimensional of livelihood assets

Description of the Figure 5 and 6 :

$\mathrm{AP}=$ Personal Asset, $\mathrm{AS}=$ Social Asset, $\mathrm{AF}=$ Financial Asset, $\mathrm{APh}=$ Physical Asset, $\mathrm{AH}=$ Human Asset, $\mathrm{KL}=$ Environmental Welfare, $\mathrm{KS}=$ Subjective Welfare, $\mathrm{KI}=$ Core Welfare, $\mathrm{ND}=$ Need

\subsection{Personal Assets as Main Actor of Sustainable Livelihoods Establishment}

To explain sustainability, required multiple disciplines [28]. Meanwhile, to achieve sustainability by [29] not only have to focus on the spectrum of concerns with environmental issues, socio-economic and social quality of life issues, but we also have to achieve a substantial shift in values, attitudes, and pro-environmental behavior (or PEBS) which sustainable and a community lifestyle. Therefore to explain poverty, gender and women, personal assets is one of the important dimensions of sustainable livelihood assets [1], even according to [14], personal asset is the strength of women, which led to the process of personal transformation, as proposed by [30] that the increase in self-esteem of women after obtaining ACCESS intervention program in South Sulawesi can affect women's leadership and participation. According to [31], participation is important because it can lead to better utilization of human resources, which will improve earnings.

In the context of agricultural development, the involvement of women in the development process, it is important to be pursued in order to improve the welfare of the household. But in reality, especially in poor households is very difficult to participate in and contribute to their point of view difficult-represented. Such as those encountered in the village Malangrapat, despite having a good personal assets but they still find it difficult to participate and contribute in the development process in the village, so most of them live in poverty. Therefore, the context of agricultural development in general as well as within the framework of the livelihoods establishment and reduce poverty in particular the power of personal assets need to be considered.

There are two approaches that need to be done for the above purpose, namely internal and external approach. Internal approach in question is a personal asset optimization, by strengthening the "self-efficacy", while the external approach is required government intervention to promote "learned helplessness" with empowerment programs. Self-efficacy is a person's judgment about his ability to do certain activities. According to [32] there is a risk for people with low social capital because they feel that they can not contribute to the discussion, so that 'important message of poverty' they are not included in development work. Many studies show that the relationship between self-efficacy and self-esteem to the welfare, among others, the difference in self-efficacy and self-esteem among women working and not working. Self-efficacy of women working (included) is higher than women who do not work (not included), so it can also be concluded that there is a strong relationship between self-efficacy with welfare [33], thus, for self-efficacy and self-esteem of women who are married and work [34]. Different employment status (professional, non-professional and unemployed women) showed differences in self-efficacy and self-esteem is significantly different, where women with professional jobs have higher value of self-efficacy and self-esteem than unemployed women. So that selfefficacy can be described as a catalyst for increased prosperity. Individuals who have high belief in self-efficacy and self-esteem, can produce strong feelings for prosperous.

Related context of personal assets, something needed in life skills a person to establish sustainable livelihoods is the "soft skills". According to [35] the soft skills are communication skills, group skills, ethics and 
moral and spiritual skills. [36] mentioned something that can bring soft touch to the "soft skills" to promote themselves, necessary 'branding and bragging'.

Branding is a picture that appears to people thinking of us, while bragging is the most powerful tool to convey a message about our branding.

Besides efforts to promote itself through the strengthening of personal assets internally above, is also required government intervention to promote helplessness fishermen households headed by women through empowerment efforts. As expressed by Petersen et al, 1993 in [37], that the people who experience disability, will not be able to affect their own lives, the growing despair and passive attitude, and they will stop engaging in activities that could make their lives better.

\section{CONCLUSION}

Various poverty alleviation efforts that have been promoted during this time are not yet able to provide a significant impact to the improvement of sustainable prosperity, especially for fishermen households. One dimension which is very rarely discussed within the framework of agricultural development is the power of personal assets. Result of this observation showed a significant relationship between the personal assets of the sustainable status of fishermen household's livelihoods, where of several livelihood assets dimensions that most influence the creation of a sustainable status is a personal asset. It can be concluded that the failure of various empowerment programs because it is not supported by the power of personal assets. So, it is necessary to consider personal asset into an early priority before making an effort to empower other livelihood assets mainly within the framework of sustainable agricultural development.

\section{REFERENCES}

[1] IFAD, 2002. Assessment of Rural Poverty. International Fund for Agricultural Development (IFAD). 2002. Asia and the Pacific, IFAD, Rome. http://www.ifad.org

[2] Chant, S. 2007. Poverty Begins at Home? Questioning some (mis) Conceptions About Children, Poverty and Privation in FemaleHeaded Households. Revised paper for UNICEF Report on State of the World's Children 2007. www.unicef.org/sowc07/docs/chant.pdf.

[3] Lin, X Xingchen ChiaChi, Female Heads of Households in Eurasian Societies. Taipei and Rotterdam in times of industrialization, Doctoral diss., Universiteit Nijmegen. Taiwan, 2011. (http://hdl.handle.net/2066/91256)

[4] Howard, T., 2007. The Effects of Poverty on Female-Headed Households (Article). University of Tennessee at Chattanooga BSW Social Work Program Spring 2007. SOCW 376.

[5] Sumner, C., 2011. Akses terhadap Keadilan: Pemberdayaan Perempuan Kepala Keluarga di Indonesia: Studi Kasus di Provinsi Nanggroe Aceh Darussalam, Jawa Barat, Kalimantan Barat, dan Nusa Tenggara Timur. (Laporan Penelitian kerjasama antara pemerintah Indonesia dan Australia melalui Australia Legal Development Facility (IALDF) dan Australian Agency of International Development (AusAID)

[6] KP3A RI, 2011. Profil Perempuan Indonesia. Kementerian Pemberdayaan Perempuan dan Perlindungan Anak. Jakarta. http://menegpp.go.id/V2/index.php/daftar-buku/profil-perempuan

[7] TNP2K. 2012. Kumpulan Tanya-jawab Program-program Penanggulangan Kemiskinan. Tim Nasional Percepatan Penanggulangan Kemiskinan (TNP2K). Sekretariat Wakil Presiden Republik Indonesia. Cet 1 Desember 2012. Jakarta. Available at: www.tnp2k.go.id

[8] BPPKS. 2012. Kementerian Sosial Dalam Angka. Pembangunan Kesejahteraan Sosial. Kementerian Sosial Republik Indonesia. Badan Pendidikan dan Penelitian Kesejahteraan Sosial Pusat Data dan Informasi Kesejahteraan Sosial Jakarta.

[9] PEKKA. 2012. Sepuluh Tahun PEKKA (Laporan: Desember 2001-Desember 2011). Pemberdayaan Perempuan Kepala Keluarga (PEKKA). Jakarta. http://www.pekka.or . id

[10] BPS. 2013. Profil Kemiskinan di Indonesia Maret 2013. Berita Resmi Statistik, BPS. No. No. 47/07/Th. XVI, 1 Juli 2013

[11] Messer, N and P, Townsley. 2003. Local institutions and livelihoods: Guidelines for analysis. Rural Development Division Food And Agriculture organization of The United Nations, Rome.

[12] Kates, R.W., 2011. What kind of a science is sustainability science? Proceedings of the National Academy of Sciences, Vol. 108, No. 49, 99. 19449-19450, doi: 10.1073/pnas.1116097108. http://www.rwkates.org

[13] Krantz, L. 2001. The Sustainable Livelihood Approach to Poverty Reduction. An Introduction. Swedish International Development Cooperation Agency (SIDA). Stockholm, Sweden. http://www.sida.se

[14] Murray, Janet and Mary. Ferguson, 2002. A Guide to Effective Practice in Promoting Sustainable Livelihoods through Enterprise Development (Women and Economic Development Consortium: January 2002). Levi Strauss \& Co. (Canada). http://cdnwomen.org/eng/pdfs/WIT.pract.gde.full.pdf

[15] Murray, Janet and Mary. Ferguson, 2001. Women in Transition Out of Poverty: An asset based approach to building sustainable livelihoods (Women and Economic Development Consortium: February 2001). http://cdnwomen.org/eng/pdfs/wit.asset.bsd.full.pdf

[16] Yin, Robert, K. 1989. Case Study Research: Design and Methods, London: Sage Publication.

[17] Moleong, Lexy J., 2001. Metodologi Penelitian Kualitatif, PT. Rosdakarya, Bandung.

[18] Arikunto, Suharsimi. 2005, Manajemen Penelitian. Cetakan Ketujuh, Penerbit Rineka Cipta, Jakarta.

[19] Sidloyi, Sinatemba. 2010. Survival Strategies of Elderly Women in Female-Headed Households. Thesis. The Faculty of Humanities Univesity of Pretoria

[20] Cahyat, A., C. Gönner and M. Haug. 2007. Mengkaji Kemiskinan dan Kesejahteraan Rumah Tangga: Sebuah Panduan dengan Contoh dari Kutai Barat, Indonesia. CIFOR, Bogor, Indonesia. 121p.

[21] Borgatti, S. P., Everett, M. G., \& Freeman, L. C. 2002. Ucinet for Windows: Software for Social Network Analysis. Harvard Analytic Technologies, 2006, SNA Analysis software..

[22] Hanneman, Robert A. and Mark Riddle. 2005. Introduction to social network methods. Riverside, CA: University of California, Riverside ( published in digital form at http://faculty.ucr.edu/ hanneman/ ). 
[23] Hussain, N dan S, Huda (1995). Problems of the Women Headed Households. Working Paper Number 9. The BRAC-ICDDR,B Joint Research Project Dhaka, Bangladesh

[24] BPS dan BAPPEDA Kepri. 2010, Kepulauan Riau Dalam Angka. Badan Perencanaan Pembangunan Kepulauan Riau (BAPPEDA Kepri) dan Badan Pusat Statistik (BPS), Propinsi Kepulauan Riau.

[25] Chant, S., 2003. Female Household Headship and the Feminisation of Poverty: Facts, Fictions and Forward Strategies. LSE Gender Institue, New Working Paper Series, Issue 9 (London: London School of Economics)

[26] Khalifa, Ferial. 2010. Female Headed Households in the West Bank and Gaza Strip. An Inside Perspective into their Socioeconomic Conditions and Their Experience of Being Female Heads. http://www.pwrdc.ps/site_files/FHH21March Final for website.pdf

[27] Drago, Robert, Black David and Wooden Mark. 2004. Female Breadwinner Families: Their Existence, Persistence and Sources. Forschungsinstitut zur Zukunft der Arbeit Institute for the Study of Labor (IZA). IZA DP No. 1308. September 2004.

[28] Kates, R. W., W. C. Clark, R. Corell, J. M. Hall, C., et al., 2001. Sustainability science, Science, Vol. 292 , p. 641-642. http://www.rwkates.org

[29] Pelletier, Luc (2011). Personal Autonomy and Environmental Sustainability. Paper presented at the Department of Psychology Friday, February 18, 2011 at 11:00 a.m. - noon Concordia University MB Building, Room MB 6.260 1450 Guy Street (de Maisonneuve Blvd. West). http://www.socialsciences.uottawa.ca/psy/professor-profile?id=233\&pageID=2.

[30] Utami, B., K. Yusdjam, L. Pulu dan S. Mushanif. 2010. Kepemimpinan dan Partisipasi Perempuan Dalam Membangun Kebijakan Publik Di Komunitas. Studi Kasus di Jeneponto (Sulawesi Selatan) dan Lombok Tengah (Nusa Tenggara Barat). Editor Yanti Muchtar. Laporan KAPAL Perempuan Seri Penelitian, 2010. Jakarta. Kerjasama KAPAL Perempuan, Australia Indonesia Partnership dan IDSS.

[31] Heller, F., (2003). Participation and Power: A critical Assessment, International Association for Applied Psychology, Vol. 52, No.1, pp. 144-163,London: Blackwell Publishing

[32] Narayan D, Chambers R, Shah K and Petesch P. 2000. Voices Of The Poor. Crying Out for Change. Published by Oxford University Press for the World Bank

[33] Sahoo, F.M. \& Rath, S. 2003. Need-saliency model of involvement in working and non-working women. Journal of Community Guidance and Research., 20 (3) 207-214. Dr. Fakir Mohan Sahoo : Professor, Organisational Behaviour. Email:fakirmohan@ximb.ac.in

[34] Sadeghi, A.I.A. dan P. Vasudeva (2006). Self-Efficacy and Self-esteem: A Comparative Study of Employed and Unemployed Married Women in Iran. Reprinted from the German Journal of Psychiatry. Dept. of Psychiatry, The University of Göttingen, vonSiebold-Str. 5, D-37075 Germany; http:/www. gjpsy.uni-goettingen.

[35] Elfindri, et al. 2010. Soft Skill Untuk Pendidik. Penerbit Baduose Media. Jakarta

[36] Klaus, Peggy. 2007. The Hard Truth About Soft Skill. Collins Business Publishers. New York.

[37] Franzoi, S.L., (2003). Social Psychology, $3^{\text {rd }}$ Edition, New York: McGraw-Hill 